\title{
Optimalisasi Distribusi Batik Dengan Metode Fmadm Menggunakan Bilangan Fuzzy Pada Interval Aritmatik
}

\author{
Kuzairi $^{1}$, Faisol $^{2}$, Dian Islami ${ }^{3}$ \\ 1,2,3 Jurusan Matematika, Fakultas Mipa, Universitas Islam Madura \\ Email: 1kuzairi81@gmail.com, ${ }^{2}$ faisol.munif@gmail.com, ${ }^{3}$ dianislami343@gmail.com
}

\begin{abstract}
Batik is a cloth that traditionally made using the technique of dyeing with evening and candles as the color barrier material. This during a cultural icon of Indonesian making batik became the most important part, one type of batik is batik Klampar. As for batik problems there were many problems, one of which the problem of distribution batik to achieve market share. Therefore, conducted research using fuzzy numbers at arithmetic interval so that the results of this study obtained the best alternative le the first rank is in alternative Bangkalan city with value 0,881768.

Keyword:Batik, Method Uzing Fuzzy Numbers On The Interval Arithmetic, Distribution.
\end{abstract}

\begin{abstract}
Abstrak.Batik adalah sehelai kain yang dibuat secara tradisional menggunakan teknik celup dengan malam dan lilin sebagai bahan perintang warna. Selama ini batik merupakan ikon budaya indonesia sehingga batik menjadi bagian terpenting. Salah satu jenis batik adalah batik Klampar.Adapun batik dalam permasalahannya terdapat banyak permasalahan, salah satunya masalah pendistribusian batik untuk mencapai pangsa pasar.Oleh karena itu, dilakukan penelitian menggunakan bilangan fuzzy pada interval aritmatik sehingga dari hasil penelitian ini didapat alternatif terbaik yaitu ranking pertama terdapat pada alternatif Kabupaten Bangklan dengan nilai 0,881768.
\end{abstract}

Kata Kunci: Batik, Metode Bilangan Fuzzy pada Interval Aritmatik, Pendistribusian.

\section{PENDAHULUAN}

Batik merupakan salah satu kain tradisional Indonesia. Di setiap daerah batik memiliki kekhasan yang mewakili daerah masing-masing pembatik. Kekhasan ini dipengaruhi oleh lingkungan, pengalaman spiritual, keluarga, serta jiwa sang pembatik (Sandiantoro, 2015).Dengan euforia batik saat ini yang telah digunakan pada seluruh masyarakat Indonesia maka perlu adanya proses pendistribusian batik sehingga mencapai pangsa pasar.

Distribusi adalah proses penyaluran barang dari produsen hingga ke konsumen (Hartanto, 2016).Dalam proses pendisribusian perlu adanya ketelitian karena distribusi merupakan salah satu faktor terpenting dalam pemasaran. Dalam penelitian ini dikhususkan pada pendistribusian batik di Desa Klampar yang akan didistribusikan ke beberapa tempat. Dimana antara Desa Klampar dengan tempat pendistribusian tersebut menggunakan beberapa macam jenis jasa pengiriman dengan tujuan untuk bisa mencapai distribusi yang lebih optimal ke tempat tersebut. Dalam pendistribusian terdapat beberapa kendala seperti: jenis pengiriman, jadwal pengiriman dan waktu pengiriman.Untuk memperbaiki kendala tersebut diperlukan adanya optimalisasi pendistribusian batik dengan menggunakan salah satu metode dari fuzzy MADM yaitu bilanganfuzzy pada interval aritmatik.

Fuzzy MADM adalah suatu metode yang digunakan untuk mencari alternatif optimal dari sejumlah alternatif dengan kriteria tertentu (Handayani , 2013).Penelitian yang menggunakan interval aritmatik sebelumya diteliti oleh Lodwick (2014) dalam "Interval Aritmatik Berlevel Tunggal" dengan hasil bahwa interval aritmatik bisa mengaplikasikan ke dalam konteks fuzzy sedangkan penelitian lainya yang dilakukan oleh Wibawa (2013) dalam "Optimalisasi Distribusi Gula Pasir menggunakan Metode Linear Programming" dengan hasil bahwa optimalisasi distribusi dapat digunakan untuk membantu menentukan tempat pendistribusian yang diberi prioritas. Oleh karena itu penulis tertarik untuk mengambil judul "Optimalisasi Distribusi Batik dengan Metode FMADM menggunakan Bilangan fuzzy pada Interval Aritmatik" agar dapat memudahkan dalam masalah pendistribusian batik yang lebih spesifik dan lebih teruji. 


\subsection{Metode}

\section{a. Definisi Bilangan fuzzy}

Logika fuzz yadalah ilmu yang mempelajari secara sistematis kaidah-kaidah penalaran yang valid.Ada 2 konsep logika, salah satunya adalah logika fuzzyyaitu logika yang menggunakan konsep sifat kesamaran (Ula, 2014).Bilangan fuzzy adalah himpunan fuzzy yang konvek dan normal (Nugroho, 2016).Interval aritmatik merupakan operasi dasar yang terdiri dari penjumlahan, pengurangan, perkalian dan bagian dari interval (Piegat dan Landowski, 2012). Bilangan Fuzzy Interval Aritmatik yaitu gabungan antara bilangan fuzzy dengan interval aritmatik.

\section{b. Bobot rata-rata}

Berdasarkan Kusumadewi, (2006)misalkan $W_{j t}=\left(a_{j t}, b_{j t}, c_{j t}\right), W_{j t} \in R^{+}, j=1,2, \ldots, n, t=$ $1,2, \ldots, k$ adalah bobot yang diberikan oleh pengambil keputusan $D_{t}$ terhadap kriteria $C_{j}$ bobot rata-rata, $w_{j}=\left(a_{j}, b_{j}, C_{j}\right)$ dari kriteria $C_{j}$ yang diberikan oleh $\mathrm{k}$ orang pengambil keputusan, dapat dihitung dengan:

$w_{j}=(1 \backslash k) \otimes\left(w_{j 1} \oplus w_{j 2} \oplus \ldots \oplus w_{j k}\right) \quad$ dengan:

$a_{j}=\frac{\sum_{t=1}^{k} a_{j t}}{k} b_{j}=\frac{\sum_{t=1}^{k} b_{j t}}{k} c_{j}=\frac{\sum_{t=1}^{k} c_{j t}}{k}$

Pada akhirnya, bobot rata-rata ini dapat ditransformasikan dengan formula:

$w_{j}^{\sim}=\frac{w_{j}}{\sum_{j=1}^{n} w_{j}}$

\section{c. Rating rata-rata}

Berdasarkan Kusumadewi, (2006) misalkan $x_{i j t}=\left(e_{i j t}, f_{i j t}, g_{i j t}\right), x_{i j t} \in R^{+}, i=1,2, \ldots, m ; j=$ $1,2, \ldots, n ; t=1,2, \ldots, k$ adalah rating terhadap alternatif $A_{i}$, yang diberikan oleh pengambil keputusan $D_{t}$ terhadap kriteria $C_{j}$. Rating rata-rata untuk alternatif $A_{i}$ dari kriteria $C_{j}$ yang diberikan oleh k orang yang mengambil keputusan, $x_{i j}=\left(e_{i j}, f_{i j}, g_{i j}\right)$, dapat dihitung dengan:

$e_{i j}=\frac{\sum_{t=1}^{k} e_{i j t}}{k} f_{i j}=\frac{\sum_{t=1}^{k} f_{i j t}}{k} \quad g_{i j}=\frac{\sum_{t=1}^{k} g_{i j t}}{k}$

Apabila kriteria diklasifikasikan dalam Benefit (B), dan Cost (C), maka pada akhirnya, rating rata-rata ini dapat ditrpansformasikan dengan formula:

$x_{i j}^{-}=\frac{x_{i j}}{\sum_{i=1}^{m} x_{i j}} ; \quad \quad$ untuk setiap $j \in B$ atau

$x_{i j}^{-}=\frac{\left(x_{i j}^{+}+x_{i j}^{-}-x_{i j}\right)}{\sum_{i=1}^{m} x_{i j}}$; untuk setiap $J \in C$;

dengan: $x_{i j}^{+}=\max _{i} ; x_{i j}^{-}=\min \left(x_{i j}\right)$;

\section{d. Fungsi keanggotaan untuk setiap rating terbobot yang sudah ditransformasi}

Berdasarkan Kusumadewi, (2006) fungsi keanggotaan untuk setiap rating terbobot yang sudah ditransformasi, yaitu:

$r_{i j}=x_{i j}^{-} \otimes w_{j}$, dapat dikembangkan dengan menggunakan interval aritmatik dari bilangan fuzzy.Dengan menggunakan persamaan (1), (3), dan (4), $\alpha$-cut untuk $r_{i j}=x_{i j}^{-} \otimes w_{j}$ dapat direpresentasikan dengan:

$$
\begin{aligned}
& r_{i j}=\left(\frac{V_{i j}}{V_{j}}, \frac{Y_{i j}}{Y_{j}}, \frac{Z_{i j}}{Z_{j}} ; K_{i j 1}, L_{i j 1}, M_{j 1}, N_{j 1} ; K_{i j 2}, L_{i j 2}, M_{j 2}, N_{j 2}\right) ;=1,2, \ldots, \mathrm{m} \\
& s_{i j}=\left(o_{i j}, p_{i j}, q_{i j}\right)=\left\{\begin{array}{cc}
x_{i j} ; & j \in \text { Benefit } \\
x_{i j}^{+}+x_{i j}^{-}-x_{i j} ; & j \in \text { Cost }
\end{array}\right. \\
& V_{i j}=o_{i j} a_{j} ; \\
& V_{j}=\sum_{i=1}^{m} g_{i j} \sum_{j=1}^{n} c_{j ;} \\
& Y_{i j}=p_{i j} b_{j} ; \\
& Y_{j}=\sum_{i=1}^{m} f_{i j} \sum_{j=1}^{n} b_{j ;} \\
& Z_{i j}=q_{i j} c_{j} ; \\
& Z_{j}=\sum_{i=1}^{m} e_{i j} \sum_{j=1}^{n} a_{j} \\
& K_{i j 1}=\left(p_{i j}-o_{i j}\right)\left(b_{j}-a_{j}\right) ; \\
& L_{i j 1}=o_{i j}\left(b_{j}-a_{j}\right)+a_{j}\left(p_{i j}-o_{i j}\right) ;
\end{aligned}
$$




$$
\begin{aligned}
M_{j 1} & =\left(\sum_{i=1}^{m} f_{i j}-\sum_{i=1}^{m} g_{i j}\right)\left(\sum_{j=1}^{n} b_{j}-\sum_{j=1}^{n} c_{j}\right) \\
& N_{j 1}=\sum_{i=1}^{m} g_{i j}\left(\sum_{j=1}^{n} b_{j}-\sum_{j=1}^{n} c_{j}\right)+\sum_{j=1}^{n} c_{j}\left(\sum_{i=1}^{m} f_{i j}-\sum_{i=1}^{m} g_{i j}\right) \\
K_{i j 2} & =\left(p_{i j}-q_{i j}\right)+\left(b_{j}-c_{j}\right) ; \\
& L_{i j 2}=q_{i j}\left(b_{j}-c_{j}\right)+c_{j}\left(p_{i j}-q_{i j}\right) ; \\
& M_{j 2}=\left(\sum_{i=1}^{m} f_{i j}-\sum_{i=1}^{m} e_{i j}\right)\left(\sum_{j=1}^{n} b_{j}-\sum_{j=1}^{n} a_{j}\right) \\
& N_{j 2}=\sum_{i=1}^{m} e_{i j}\left(\sum_{j=1}^{n} b_{j}-\sum_{j=1}^{n} a_{j}\right)+\sum_{j=1}^{n} a_{j}\left(\sum_{i=1}^{m} f_{i j}-\sum_{i=1}^{m} e_{i j}\right) \\
\text { e. Penentuan urutan alternatif } & \text { P }
\end{aligned}
$$

\section{e. Penentuan urutan alternatif}

Berdasarkan Kusumadewi, (2006) untuk menentukan urutan setiap alternatif, dapat digunakan formula

$S_{i}=\sum_{j=1}^{n} r_{i j}^{\prime}$

Dengan $r_{i j}^{\prime}$ adalah nilai defuzzy dari $r_{i j}$. Ada beberapa metode perankingan yang bisa digunakan pada bilangan fuzzy berbentuk segitiga menggunakan metode total integral value untuk bilangan fuzzy $F=(a, b, c)$ yaitu:

$1_{T}^{\alpha}=\frac{1}{2}(\alpha \mathrm{c}+\mathrm{b}+(1-\alpha) \mathrm{a})$

Dengan a merupakan derajat keoptimisan yang bernilai: $0 \leq \alpha \leq 1$

Urutan ranking nantinya akan ditentukan oleh besar kecilnya $S_{i}$. Nilai $S_{i}$ yang lebih besar akan menempatiranking yang lebih tinggi.

\section{TINJAUAN PUSTAKA}

\subsection{Pengertian Batik}

Kata batik menurut salah satu sumber berasal dari dua kata bahasa jawa yaitu "amba" yang bermakna menulis dan " $t i k$ " yangbermakna titik atau tetes. Kata " $i k$ " ini diduga berasal dari inti cara membatik yang mempergunakan proses "penutupan" yaitu menutup bagian-bagian pada kain atau bahan lain yang tidak hendak diberi warna dengan lilin atau malan. Cara menutupnya dilakukan dengan meneteskan lilin pada kain (Sastrodiwirjo, 2012).

Batik merupakan salah satu budaya Indonesia, namun saat ini tidak hanya diakui oleh masyarakat Indonesia tetapijuga diakui dunia. Pada tanggal 2 oktober 2009, UNESCO (United Nations Educational Scientific, and Cultural Organization) menetapkan batik sebagai warisan budaya dunia yang berasal dari Indonesia dengan istilah "Warisan Kemanusiaan untuk Budaya Lisan dan Nonbendawi". Batik dinilai sebagai ikon budaya yang memiliki keunikan dan filosofi yang mendalam, serta mencakup siklus kehidupan manusia. Pokok pertimbangan yang dipergunakan UNESCO dalam menetapkan penghargaan tersebut, antara lain karena batik di Indonesia merupakan kerajinan tradisional turun temurun yang kaya akan nilai dan budaya. Pengakuan UNESCO mendorong dan memperkuat tekad bangsa Indonesia untuk terus-menerus mengembangkan batik, sehingga tidak perlu merasa khawatir bahwa batik Indonesia akan punah (Sastrodiwirjo, 2012).

\subsection{Distribusi}

Distribusi adalah proses penyaluran barang dari produsen hingga ke konsumen (Hartanto, 2016).Pendistribusian barang atau jasa merupakan salah satu bagian terpenting dari kegiatan sebuah instansi pemerintah ataupun perusahaan tertentu (Wibawa, 2013).

\subsection{Logika fuzzy}

Logika adalah ilmu yang mempelajari secara sistematis kaidah-kaidah penalaran yang falid.Ada 2 konsep logika, salah satunya adalah logika fuzzy. Logika fuzzy logika yang menggunakan konsep sifat kesamaran, Sehingga logika fuzzy disebut logika dengan tak hingga banyak nilai kebenaran yang dinyatakan dalam bilangan real dalam selang $(0,1)$. Logika fuzzy adalah suatu cara yang tepat untuk memetakan suatu ruang input kedalam suatu ruang output, mempunyai nilai kontinu. Fuzzy dinyatakan dalam derajat dari suatu keanggotaan dan derajat dari kebenaran.Logika fuzzy termasuk logika yang mudah, sangat fleksibel, memiliki toleransi terhadap data yang tidak tepat, logika fuzzy didasarkan pada bahasa alami yaitu menggunakan bahasa sehari-hari sehingga mudah dimengerti (Ula, 2014). 


\subsection{Fuzzy MADM}

Pada dasarnya, proses MADM dilakukan melalui tiga tahap, yaitu penyusunan komponenkomponen situasi, analisis dan sintesis informasi. Pada tahap penyusunan komponen-komponen situasi, akan dibentuk tabel taksiran yang berisi identifikasi alternatif dan spesifikasi tujuan, kriteria dan atribut. Salah satu cara untuk menspesifikasikan tujuan situasi $\left|o_{i}, i=1, \ldots, t\right|$ adalah dengan cara mendaftar konsekuensi-konsekuensi yang mungkin dari alternatif yang telah teridentifikasi $\mid A_{i}, i=$ $1, \ldots, n \mid$.Selain itu juga disusun atribut-atribut yang akan digunakan $\left|a_{k}, k=1, \ldots m\right|$.

Tahap analisis dilakukan melalui dua langkah.Pertama, mendatangkan taksiran dan besaran yang potensial, kemungkinan, dan ketidakpastian yang berhubungan dengan dampak-dampak yang mungkin pada setiap alternatif.Kedua, meliputi pemilihan dari preferensi pengambil keputusan untuk setiap nilai, dan ketidakpedulian terhadap resiko yang timbul.Pada langkah pertama, beberapa metode menggunakan fungsi distribusi $|p j(x)|$ yang menyatakan probabilitas kumpulan atribut $\left|a_{k}\right|$ terhadap setiap alternatif $\left|A_{i}\right|$.Konsekuensi juga dapat ditentukan secara langsung dari agregasi sederhana yang dilakukan pada informasi terbaik yang tersedia. Demikian pula, ada beberapa cara untuk menentukan prefensi pengambil keputusan pada setiap konsekuen yang dapat dilakukan pada langkah kedua. Metode yang paling sederhana adalah untuk menurunkan bobot atribut dan kriteria adalah dengan utilitas atau penjumlahan terbobot (Buhari, 2016).

\section{METEDE PENELITIAN}

Metode penelitian dalam penelitian ini dapat dilihat dilihat pada Gambar 1

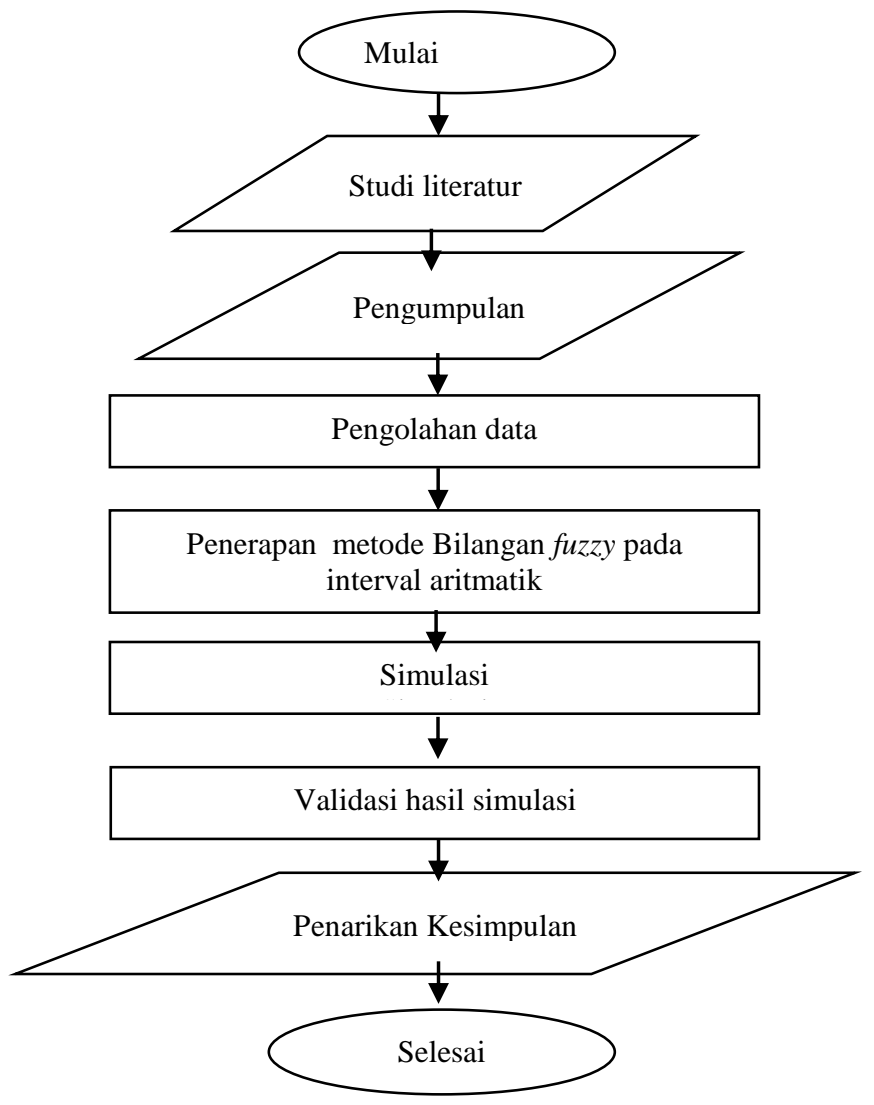

Gambar. 1 MetodePenelitian

\section{PEMBAHASAN}

\subsection{Data dan Lokasi Penelitian}

Data diambil melalui observasi dalam bentuk kuesioner pada pengusaha batik di Desa Klampar, data yang diambil adalah data pendistribusian batik selama tahun 2016 dengan 5 alternatif dan 3 kriteria yaitu jenis pengiriman, jadwal pendistribusian dan waktu pendistribusian. Pada Tabel 1 dan 2 dapat dilihat bahwa hasil data pada masing-masing kriteria oleh setiap pengambil keputusan. pada Tabel 1dapat dilihat bahwa data pada bobot setiap kriteria untuk setiap pengambil keputusan. 
Tabel 1 Bobot Setiap Kriteria untuk Setiap Pengambil Keputusan

\begin{tabular}{cccccc}
\hline Kriteria & \multicolumn{5}{c}{ Pengambil Keputusan } \\
\hline & $D_{1}$ & $D_{2}$ & $D_{3}$ & $D_{4}$ & $D_{5}$ \\
\hline$C_{1}$ & 0,8 & 1 & 0,8 & 0,6 & 0,8 \\
\hline$C_{2}$ & 0,6 & 1 & 1 & 0,8 & 0,8 \\
\hline$C_{3}$ & 1 & 1 & 0,8 & 0,6 & 0,8 \\
\hline
\end{tabular}

Pada Tabel 2 dapat dilihat bahwa rating setiap alternatif pada setiap kriteria oleh setiap pengambil keputusan.

Tabel 2Rating Setiap Alternatif Pada Setiap Kriteria

\begin{tabular}{ccccccc}
\hline Kriteria & Alternatif & \multicolumn{5}{c}{ Pengambil Keputusan } \\
\hline \multirow{5}{*}{$C_{1}$} & & $D_{1}$ & $D_{2}$ & $D_{3}$ & $D_{4}$ & $D_{5}$ \\
\cline { 2 - 7 } & $A_{1}$ & 8 & 10 & 8 & 8 & 8 \\
\cline { 2 - 7 } & $A_{2}$ & 10 & 10 & 8 & 6 & 8 \\
\cline { 2 - 7 } & $A_{3}$ & 8 & 10 & 8 & 6 & 8 \\
\cline { 2 - 7 } & $A_{4}$ & 8 & 10 & 8 & 6 & 8 \\
\cline { 2 - 7 } & $A_{5}$ & 8 & 4 & 8 & 10 & 4 \\
\hline \multirow{3}{*}{$C_{2}$} & $A_{1}$ & 2,4 & 4 & 4 & 3,2 & 3,2 \\
\cline { 2 - 7 } & $A_{2}$ & 4 & 4 & 4 & 3,2 & 3,2 \\
\cline { 2 - 7 } & $A_{3}$ & 2,4 & 4 & 4 & 3,2 & 3,2 \\
\cline { 2 - 7 } & $A_{4}$ & 2,4 & 4 & 4 & 3,2 & 3,2 \\
\hline$C_{3}$ & $A_{5}$ & 2,4 & 1,6 & 4 & 4 & 4 \\
\cline { 2 - 7 } & $A_{1}$ & 7 & 7 & 4,2 & 7 & 4,2 \\
\cline { 2 - 7 } & $A_{2}$ & 7 & 5,6 & 5,6 & 5,6 & 4,2 \\
\hline & $A_{3}$ & 5,6 & 5,6 & 5,6 & 4,2 & 4,2 \\
\hline & $A_{4}$ & 5,6 & 5,6 & 5,6 & 5,6 & 4,2 \\
& $A_{5}$ & 2,8 & 1,4 & 2,8 & 7 & 7 \\
\hline
\end{tabular}

Keterangan: $A_{1}=$ Bangkalan, $A_{2}=$ Surabaya, $A_{3}=$ Malang,$A_{4}=$ sidoarjo, $A_{5}=$ Jakarta,$\quad C_{1}=$ Jenis pengiriman, $C_{2}=$ Jadwal pengiriman, $C_{3}=$ Waktu pengiriman

\subsection{Perubahan Data ke Bentuk Fuzzy}

Pada Tabel 3 dapat dilihat bahwa hasil perubahan data pada bobot setiap kriteria. nilai-nilai tersebut merupakan nilai masing-masing dari salah satu hasil pengujian dari 5 data yang akan dirubah kebentuk fuzzy menggunakan rumus $(\mathrm{x}-2),(\mathrm{x}),(\mathrm{x}+2)$.

Tabel 3Perubahan Data Pada Bobot Setiap Kriteria

\begin{tabular}{cccccc}
\hline Kriteria & $D_{1}$ & $D_{2}$ & $D_{3}$ & $D_{4}$ & $D_{5}$ \\
\hline$C_{1}$ & $1 ; 1 ; 2,8$ & $1 ; 1 ; 3$ & $1 ; 1 ; 2,8$ & $1 ; 1 ; 2,6$ & $1 ; 1 ; 2,8$ \\
\hline$C_{2}$ & $1 ; 1 ; 2,6$ & $1 ; 1 ; 3$ & $1 ; 1 ; 3$ & $1 ; 1 ; 2,8$ & $1 ; 1 ; 2,8$ \\
\hline$C_{3}$ & $1 ; 1 ; 3$ & $1 ; 1 ; 3$ & $1 ; 1 ; 2,8$ & $1 ; 1 ; 2,6$ & $1 ; 1 ; 2,8$ \\
\hline
\end{tabular}

\subsection{Perubahan Data Rating Setiap Alternatif pada Setiap Kriteria}

Pada Tabel 4 dapat dilihat bahwa hasil perubahan data ke bentuk fuzzy untuk rating setiap alternatif pada setiap kriteria.

Tabel. 4 Perubahan Data Rating Setiap Alternatif

\begin{tabular}{ccccccc}
\hline & \multicolumn{7}{c}{ Pengambil keputusan } \\
\hline$C_{1}$ & & $D_{1}$ & $D_{2}$ & $D_{3}$ & $D_{4}$ & $D_{5}$ \\
\cline { 2 - 7 } & $A_{1}$ & $(6 ; 8 ; 9)$ & $(8 ; 9 ; 9)$ & $(6 ; 8 ; 9)$ & $(6 ; 8 ; 9)$ & $(6 ; 8 ; 9)$ \\
\cline { 2 - 7 } & $A_{2}$ & $(8 ; 9 ; 9)$ & $(8 ; 9 ; 9)$ & $(6 ; 8 ; 9)$ & $(4 ; 6 ; 8)$ & $(6 ; 8 ; 9)$ \\
\cline { 2 - 7 } & $A_{3}$ & $(6 ; 8 ; 9)$ & $(8 ; 9 ; 9)$ & $(6 ; 8 ; 9)$ & $(4 ; 6 ; 8)$ & $(6 ; 8 ; 9)$ \\
\cline { 2 - 7 } & $A_{4}$ & $(6 ; 8 ; 9)$ & $(8 ; 9 ; 9)$ & $(6 ; 8 ; 9)$ & $(4 ; 6 ; 8)$ & $(6 ; 8 ; 9)$ \\
\cline { 2 - 7 } & $A_{5}$ & $(6 ; 8 ; 9)$ & $(2 ; 4 ; 6)$ & $(6 ; 8 ; 9)$ & $(8 ; 9 ; 9)$ & $(2 ; 4 ; 6)$ \\
\hline$C_{2}$ & $A_{1}$ & $(1 ; 2,4 ; 4,4)$ & $(2 ; 4 ; 6)$ & $(2 ; 4 ; 6)$ & $(1,2 ; 3,2 ; 5,2)$ & $(1,2 ; 3,2 ; 5,2)$ \\
\hline
\end{tabular}




\begin{tabular}{ccccccc}
\hline & $A_{2}$ & $(2 ; 4 ; 6)$ & $(2 ; 4 ; 6)$ & $(2 ; 4 ; 6)$ & $(1,2 ; 3,2 ; 5,2)$ & $(1,2 ; 3,2 ; 5,2)$ \\
\cline { 2 - 7 } & $A_{3}$ & $(1 ; 2,4 ; 4,4)$ & $(2 ; 4 ; 6)$ & $(2 ; 4 ; 6)$ & $(1,2 ; 3,2 ; 5,2)$ & $(1,2 ; 3,2 ; 5,2)$ \\
\hline & $A_{4}$ & $(1 ; 2,4 ; 4,4)$ & $(2 ; 4 ; 6)$ & $(2 ; 4 ; 6)$ & $(1,2 ; 3,2 ; 5,2)$ & $(1,2 ; 3,2 ; 5,2)$ \\
\cline { 2 - 7 } & $A_{5}$ & $(1 ; 2,4 ; 4,4)$ & $(1 ; 1,6 ; 3,6)$ & $(2 ; 4 ; 6)$ & $(2 ; 4 ; 6)$ & $(2 ; 4 ; 6)$ \\
\hline$C_{3}$ & $A_{1}$ & $(5 ; 7 ; 9)$ & $(5 ; 7 ; 9)$ & $(2,2 ; 4,2 ; 6,2)$ & $(5 ; 7 ; 9)$ & $(2,2 ; 4,2 ; 6,2)$ \\
\cline { 2 - 7 } & $A_{2}$ & $(5 ; 7 ; 9)$ & $(3,6 ; 5,6 ; 7,6)$ & $(3,6 ; 5,6 ; 7,6)$ & $(3,6 ; 5,6 ; 7,6)$ & $(2,2 ; 4,2 ; 6,2)$ \\
\cline { 2 - 7 } & $A_{3}$ & $(3,6 ; 5,6 ; 7,6)$ & $(3,6 ; 5,6 ; 7,6)$ & $(3,6 ; 5,6 ; 7,6)$ & $(2,2 ; 4,2 ; 6,2)$ & $(2,2 ; 4,2 ; 6,2)$ \\
\hline & $A_{4}$ & $(3,6 ; 5,6 ; 7,6)$ & $(3,6 ; 5,6 ; 7,6)$ & $(3,6 ; 5,6 ; 7,6)$ & $(3,6 ; 5,6 ; 7,6)$ & $(2,2 ; 4,2 ; 6,2)$ \\
\hline & $A_{5}$ & $(1 ; 2,8 ; 4,8)$ & $(1 ; 1,4 ; 3,4)$ & $(1 ; 2,8 ; 4,8)$ & $(5 ; 7 ; 9)$ & $(5 ; 7 ; 9)$ \\
\hline
\end{tabular}

\subsection{Penerapan Bilangan Fuzzy pada Interval Aritmatik}

\subsubsection{Bobot dan Rating Setiap Alternatif pada Setiap Kriteria}

Pada Tabel 5 dapat dilihat bahwa hasil setiap pengambil keputusan memberikan bobot untuk setiap kriteria, dan pada Tabel 6 dapat dilihat hasil rating setiap alternatif untuk setiap kriteria.

Tabel 5 Bobot Setiap Kriteria Untuk Setiap Pengambil Keputusan

\begin{tabular}{cccccc}
\hline Kriteria & $D_{1}$ & $D_{2}$ & $D_{3}$ & $D_{4}$ & $D_{5}$ \\
& & & & & \\
\hline$C_{1}$ & $1 ; 1 ; 2,8$ & $1 ; 1 ; 3$ & $1 ; 1 ; 2,8$ & $1 ; 1 ; 2,6$ & $1 ; 1 ; 2,8$ \\
\hline$C_{2}$ & $1 ; 1 ; 2,6$ & $1 ; 1 ; 3$ & $1 ; 1 ; 3$ & $1 ; 1 ; 2,8$ & $1 ; 1 ; 2,8$ \\
\hline$C_{3}$ & $1 ; 1 ; 3$ & $1 ; 1 ; 3$ & $1 ; 1 ; 2,8$ & $1 ; 1 ; 2,6$ & $1 ; 1 ; 2,8$ \\
\hline
\end{tabular}

Tabel. 6 Rating Setiap Alternatif pada Setiap Kriteria Oleh Setiap Pengambil Keputusan

\begin{tabular}{|c|c|c|c|c|c|c|}
\hline & & \multicolumn{5}{|c|}{ Pengambil keputusan } \\
\hline & & $D_{1}$ & $D_{2}$ & $D_{3}$ & $D_{4}$ & $D_{5}$ \\
\hline \multirow[t]{5}{*}{$C_{1}$} & $A_{1}$ & $(6 ; 8 ; 9)$ & $(8 ; 9 ; 9)$ & $(6 ; 8 ; 9)$ & $(6 ; 8 ; 9)$ & $(6 ; 8 ; 9)$ \\
\hline & $A_{2}$ & $(8 ; 9 ; 9)$ & $(8 ; 9 ; 9)$ & $(6 ; 8 ; 9)$ & $(4 ; 6 ; 8)$ & $(6 ; 8 ; 9)$ \\
\hline & $A_{3}$ & $(6 ; 8 ; 9)$ & $(8 ; 9 ; 9)$ & $(6 ; 8 ; 9)$ & $(4 ; 6 ; 8)$ & $(6 ; 8 ; 9)$ \\
\hline & $A_{4}$ & $(6 ; 8 ; 9)$ & $(8 ; 9 ; 9)$ & $(6 ; 8 ; 9)$ & $(4 ; 6 ; 8)$ & $(6 ; 8 ; 9)$ \\
\hline & $A_{5}$ & $(6 ; 8 ; 9)$ & $(2 ; 4 ; 6)$ & $(6 ; 8 ; 9)$ & $(8 ; 9 ; 9)$ & $(2 ; 4 ; 6)$ \\
\hline \multirow[t]{5}{*}{$C_{2}$} & $A_{1}$ & $(1 ; 2,4 ; 4,4)$ & $(2 ; 4 ; 6)$ & $(2 ; 4 ; 6)$ & $(1,2 ; 3,2 ; 5,2)$ & $(1,2 ; 3,2 ; 5,2)$ \\
\hline & $A_{2}$ & $(2 ; 4 ; 6)$ & $(2 ; 4 ; 6)$ & $(2 ; 4 ; 6)$ & $(1,2 ; 3,2 ; 5,2)$ & $(1,2 ; 3,2 ; 5,2)$ \\
\hline & $A_{3}$ & $(1 ; 2,4 ; 4,4)$ & $(2 ; 4 ; 6)$ & $(2 ; 4 ; 6)$ & $(1,2 ; 3,2 ; 5,2)$ & $(1,2 ; 3,2 ; 5,2)$ \\
\hline & $A_{4}$ & $(1 ; 2,4 ; 4,4)$ & $(2 ; 4 ; 6)$ & $(2 ; 4 ; 6)$ & $(1,2 ; 3,2 ; 5,2)$ & $(1,2 ; 3,2 ; 5,2)$ \\
\hline & $A_{5}$ & $(1 ; 2,4 ; 4,4)$ & $(1 ; 1,6 ; 3,6)$ & $(2 ; 4 ; 6)$ & $(2 ; 4 ; 6)$ & $(2 ; 4 ; 6)$ \\
\hline \multirow[t]{5}{*}{$C_{3}$} & $A_{1}$ & $(5 ; 7 ; 9)$ & $(5 ; 7 ; 9)$ & $(2,2 ; 4,2 ; 6,2)$ & $(5 ; 7 ; 9)$ & $(2,2 ; 4,2 ; 6,2)$ \\
\hline & $A_{2}$ & $(5 ; 7 ; 9)$ & $(3,6 ; 5,6 ; 7,6)$ & $(3,6 ; 5,6 ; 7,6)$ & $(3,6 ; 5,6 ; 7,6)$ & $(2,2 ; 4,2 ; 6,2)$ \\
\hline & $A_{3}$ & $(3,6 ; 5,6 ; 7,6)$ & $(3,6 ; 5,6 ; 7,6)$ & $(3,6 ; 5,6 ; 7,6)$ & $(2,2 ; 4,2 ; 6,2)$ & $(2,2 ; 4,2 ; 6,2)$ \\
\hline & $A_{4}$ & $(3,6 ; 5,6 ; 7,6)$ & $(3,6 ; 5,6 ; 7,6)$ & $(3,6 ; 5,6 ; 7,6)$ & $(3,6 ; 5,6 ; 7,6)$ & $2,2 ; 4,2 ; 6,2)$ \\
\hline & $A_{5}$ & $(1 ; 2,8 ; 4,8)$ & $(1 ; 1,4 ; 3,4)$ & $(1 ; 2,8 ; 4,8)$ & $(5 ; 7 ; 9)$ & $(5 ; 7 ; 9)$ \\
\hline
\end{tabular}

\subsubsection{Mencari Bobot Rata-Rata pada SetiapKriteria}

Pada Tabel 7 dapat dilihat bahwa hasil perhitungan bobot rata-rata untuk setiap kriteriadengan menggunakan persamaan (1).

Tabel 7 Bobot Rata-Rata Setiap Kriteria

\begin{tabular}{ccccccc}
\hline Kriteria & \multicolumn{1}{c}{$D_{1}$} & $D_{2}$ & \multicolumn{1}{c}{$D_{3}$} & $D_{4}$ & $D_{5}$ & Bobot rata-rata \\
& & & & & & \\
\hline$C_{1}$ & $1 ; 1 ; 2,8$ & $1 ; 1 ; 3$ & $1 ; 1 ; 2,8$ & $1 ; 1 ; 2,6$ & $1 ; 1 ; 2,8$ & $(1 ; 1 ; 2,8)$ \\
\hline$C_{2}$ & $1 ; 1 ; 2,6$ & $1 ; 1 ; 3$ & $1 ; 1 ; 3$ & $1 ; 1 ; 2,8$ & $1 ; 1 ; 2,8$ & $(1 ; 1 ; 2,84)$ \\
\hline$C_{3}$ & $1 ; 1 ; 3$ & $1 ; 1 ; 3$ & $1 ; 1 ; 2,8$ & $1 ; 1 ; 2,6$ & $1 ; 1 ; 2,8$ & $(1 ; 1 ; 2,84)$ \\
\hline
\end{tabular}

\subsubsection{Mencari Rating Rata-Rata Setiap Alternatif untuk Setiap Kriteria}

Pada Tabel 8 dapat dilihat bahwa hasil perhitungan rating rata-rata setiap alternatif untuk setiap kriteria dengan menggunakan persamaan (2). 
Tabel 8Rating Rata-Rata Setiap Alternatif untuk Setiap Kriteria

\begin{tabular}{|c|c|c|c|c|c|c|c|}
\hline & & \multicolumn{6}{|c|}{ Pengambil keputusan } \\
\hline & & $D_{1}$ & $D_{2}$ & $D_{3}$ & $D_{4}$ & $D_{5}$ & Rating rata-rata $X_{i j}$ \\
\hline \multirow[t]{5}{*}{$C_{1}$} & $A_{1}$ & $(6 ; 8 ; 9)$ & $(8 ; 9 ; 9)$ & $(6 ; 8 ; 9)$ & $(6 ; 8 ; 9)$ & $(6 ; 8 ; 9)$ & $(6,4 ; 8,2 ; 9)$ \\
\hline & $A_{2}$ & $(8 ; 9 ; 9)$ & $(8 ; 9 ; 9)$ & $(6 ; 8 ; 9)$ & $(4 ; 6 ; 8)$ & $(6 ; 8 ; 9)$ & $(6,4 ; 8 ; 8,8)$ \\
\hline & $A_{3}$ & $(6 ; 8 ; 9)$ & $(8 ; 9 ; 9)$ & $(6 ; 8 ; 9)$ & $(4 ; 6 ; 8)$ & $(6 ; 8 ; 9)$ & $(6 ; 7,8 ; 8,8)$ \\
\hline & $A_{4}$ & $(6 ; 8 ; 9)$ & $(8 ; 9 ; 9)$ & $(6 ; 8 ; 9)$ & $(4 ; 6 ; 8)$ & $(6 ; 8 ; 9)$ & $(6 ; 7,8 ; 8,8)$ \\
\hline & $A_{5}$ & $(6 ; 8 ; 9)$ & $(2 ; 4 ; 6)$ & $(6 ; 8 ; 9)$ & $(8 ; 9 ; 9)$ & $(2 ; 4 ; 6)$ & $(4,8 ; 6,6 ; 7,8)$ \\
\hline \multirow[t]{5}{*}{$C_{2}$} & $A_{1}$ & $(1 ; 2,4 ; 4,4)$ & $(2 ; 4 ; 6)$ & $(2 ; 4 ; 6)$ & $(1,2 ; 3,2 ; 5,2)$ & $(1,2 ; 3,2 ; 5,2)$ & $(1,48 ; 3,36 ; 5,36)$ \\
\hline & $A_{2}$ & $(2 ; 4 ; 6)$ & $(2 ; 4 ; 6)$ & $(2 ; 4 ; 6)$ & $(1,2 ; 3,2 ; 5,2)$ & $(1,2 ; 3,2 ; 5,2)$ & $(1,68 ; 3,68 ; 5,68)$ \\
\hline & $A_{3}$ & $(1 ; 2,4 ; 4,4)$ & $(2 ; 4 ; 6)$ & $(2 ; 4 ; 6)$ & $(1,2 ; 3,2 ; 5,2)$ & $(1,2 ; 3,2 ; 5,2)$ & $(1,48 ; 3,36 ; 5,36)$ \\
\hline & $A_{4}$ & $(1 ; 2,4 ; 4,4)$ & $(2 ; 4 ; 6)$ & $(2 ; 4 ; 6)$ & $(1,2 ; 3,2 ; 5,2)$ & $(1,2 ; 3,2 ; 5,2)$ & $(1,48 ; 3,36 ; 5,36)$ \\
\hline & $A_{5}$ & $(1 ; 2,4 ; 4,4)$ & $(1 ; 1,6 ; 3,6)$ & $(2 ; 4 ; 6)$ & $(2 ; 4 ; 6)$ & $(2 ; 4 ; 6)$ & $(1,6 ; 3,2 ; 5,2)$ \\
\hline \multirow[t]{5}{*}{$C_{3}$} & $A_{1}$ & $(5 ; 7 ; 9)$ & $(5 ; 7 ; 9)$ & $(2,2 ; 4,2 ; 6,2)$ & $(5 ; 7 ; 9)$ & $(2,2 ; 4,2 ; 6,2)$ & $(3,88 ; 5,88 ; 7,88)$ \\
\hline & $A_{2}$ & $(5 ; 7 ; 9)$ & $(3,6 ; 5,6 ; 7,6)$ & $(3,6 ; 5,6 ; 7,6)$ & $(3,6 ; 5,6 ; 7,6)$ & $(2,2 ; 4,2 ; 6,2)$ & $(3,6 ; 5,6 ; 7,6)$ \\
\hline & $A_{3}$ & $(3,6 ; 5,6 ; 7,6)$ & $(3,6 ; 5,6 ; 7,6)$ & $(3,6 ; 5,6 ; 7,6)$ & $(2,2 ; 4,2 ; 6,2)$ & $(2,2 ; 4,2 ; 6,2)$ & $(3,04 ; 5,04 ; 7,04)$ \\
\hline & $A_{4}$ & $(3,6 ; 5,6 ; 7,6)$ & $(3,6 ; 5,6 ; 7,6)$ & $(3,6 ; 5,6 ; 7,6)$ & $(3,6 ; 5,6 ; 7,6)$ & $(2,2 ; 4,2 ; 6,2)$ & $(3,32 ; 5,32 ; 7,32)$ \\
\hline & $A_{5}$ & $(1 ; 2,8 ; 4,8)$ & $(1 ; 1,4 ; 3,4)$ & $(1 ; 2,8 ; 4,8)$ & $(5 ; 7 ; 9)$ & $(5 ; 7 ; 9)$ & $(2,6 ; 4,2 ; 6,2)$ \\
\hline
\end{tabular}

\subsubsection{Rating terbobot ditransformasi untuk setiap alternatif $\left(\boldsymbol{r}_{i j}\right)$}

Pada Tabel 9 dapat dilihat bahwa hasil dengan menggunakan persamaan (5) sampai dengan persamaan (18) didapatkan hasil dari semua data dapat dilihat pada Tabel 9 adalah sebagai berikut:

Tabel 9Rating Terbobot ditransformasi untuk Setiap Alternatif $\left(\boldsymbol{r}_{i j}\right)$

\begin{tabular}{|c|c|c|c|c|c|c|c|c|c|c|c|}
\hline$r_{i j}$ & $V_{i j} / V_{j}$ & $Y_{i j} / Y_{j}$ & $Z_{i j} / Z_{j}$ & $K_{i j 1}$ & $L_{i j 1}$ & $M_{j 1}$ & $N_{j 1}$ & $K_{i j 2}$ & $L_{i j 2}$ & $M_{j 2}$ & $N_{j 2}$ \\
\hline$r_{11}$ & 0,0175 & 0,0712 & 0,2838 & 0 & 1,8000 & 26,3040 & $-277,4400$ & 1,4400 & $-18,4400$ & 0 & 26,4000 \\
\hline$r_{12}$ & 0,0349 & 0,1961 & 1,3350 & 0 & 1,6000 & 43,8400 & $-186,2080$ & 1,4720 & $-18,4640$ & 0 & 22,0800 \\
\hline$r_{13}$ & 0,0344 & 0,1786 & 0,9298 & 0 & 1,8000 & 32,8800 & $-163,5488$ & 1,8400 & $-19,0320$ & 0 & 16,8000 \\
\hline$r_{21}$ & 0,0164 & 0,0677 & 0,2775 & 0 & 1,8000 & 26,3040 & $-277,4400$ & 1,8000 & $-18,6400$ & 0 & 26,4000 \\
\hline$r_{22}$ & 0,0262 & 0,1618 & 1,1833 & 0 & 1,8000 & 43,8400 & $-186,2080$ & 2,2080 & $-17,7600$ & 0 & 22,0800 \\
\hline$r_{23}$ & 0,0085 & 0,0769 & 0,5663 & 0 & 1,8800 & 32,8800 & $-163,5488$ & 3,6800 & $-15,5424$ & 0 & 16,8000 \\
\hline$r_{31}$ & 0,0046 & 0,0319 & 0,1791 & 0 & 2,0000 & 26,3040 & $-277,4400$ & 3,6000 & $-15,8240$ & 0 & 26,4000 \\
\hline$r_{32}$ & 0,0081 & 0,0824 & 0,8132 & 0 & 1,8800 & 43,8400 & $-186,2080$ & 3,6800 & $-15,5424$ & 0 & 22,0800 \\
\hline$r_{33}$ & 0,0085 & 0,0769 & 0,5663 & 0 & 1,8800 & 32,8800 & $-163,5488$ & 3.6800 & $-15,5424$ & 0 & 16,8000 \\
\hline$r_{41}$ & 0,0044 & 0,0278 & 0,1640 & 0 & 1,6000 & 26,3040 & $-277,4400$ & 3,6000 & $-14,9600$ & 0 & 26,4000 \\
\hline$r_{42}$ & 0,0212 & 0,1441 & 1,1955 & 0 & 2 & 43,8400 & $-186,2080$ & 3,6800 & $-20,1792$ & 0 & 22,0800 \\
\hline$r_{43}$ & 0,0206 & 0,1282 & 0,8030 & 0 & 2,0000 & 32,8800 & $-163,5488$ & 3.6800 & $-19,6640$ & 0 & 16,8000 \\
\hline$r_{51}$ & 0,0083 & 0,0438 & 0,2220 & 0 & 2,0000 & 26,3040 & $-277,4400$ & 3,6000 & $-18,2720$ & 0 & 26,4000 \\
\hline$r_{52}$ & 0,0181 & 0,1304 & 1,1105 & 0 & 2 & 43,8400 & $-186,2080$ & 3,6800 & $-19,1488$ & 0 & 22,0800 \\
\hline$r_{53}$ & 0,0149 & 0,0962 & 0,6551 & 0 & 1,6000 & 32,8800 & $-163,5488$ & 3.6800 & $-17,0880$ & 0 & 16,8000 \\
\hline
\end{tabular}




\subsubsection{Membuat d-fuzzy $\boldsymbol{r}_{\boldsymbol{i}}^{\prime}$ dari $\boldsymbol{r}_{\boldsymbol{i}}$}

Pada Tabel 10 dapat dilihat bahwa setiap $r_{i j}$, masing-masing merupakan elemen-elemen bilangan $f u z z y$ (a,b,c), sehingga dengan derajat keoptimisan a =0,5, berdasarkan persamaan (20).

Tabel 10 Hasil d-fuzzy $\boldsymbol{r}_{i j}^{\prime}$ dari $_{i j}$

\begin{tabular}{lc}
\hline & $r^{\prime}$ \\
\hline$r^{\prime} 11$ & 0,110904 \\
\hline$r^{\prime} 12$ & 0,440535 \\
\hline$r^{\prime} 13$ & 0,3303 \\
\hline$r^{\prime} 21$ & 0,107318 \\
\hline$r^{\prime} 22$ & 0,383267 \\
\hline$r^{\prime} 23$ & 0,182161 \\
\hline$r^{\prime} 31$ & 0,061893 \\
\hline$r^{\prime} 32$ & 0,246487 \\
\hline$r^{\prime} 33$ & 0,182161 \\
\hline$r^{\prime} 41$ & 0,055972 \\
\hline$r^{\prime} 42$ & 0,376222 \\
\hline$r^{\prime} 43$ & 0,270009 \\
\hline$r^{\prime} 51$ & 0,079445 \\
\hline$r^{\prime} 52$ & 0,347356 \\
\hline$r^{\prime} 53$ & 0,21557
\end{tabular}

\subsubsection{Mencari Preferensi Alternatif $\left(s_{i}\right)$}

$$
S_{i} \quad=\sum_{j=1}^{3} r_{i 1}^{\prime}=0,110937992+0,440525+0,3305=0,8817787992
$$

\section{KESIMPULAN}

Dari hasil penelitian dapat disimpulkan bahwa, berdasarkan perhitungan manual dan matlab nilai perankingan tertinggi terdapat pada alternatif pertama yaitu Kota Bangkalan dengan nilai 0,881768, dan perankingan ke-2 terdapat pada alternatif ke-4 yaitu Kota Sidoarjo dengan nilai 0,702202, dan perankingan ke-3 terdapat pada alternatif ke-2 yaitu Kota Surabaya dengan nilai 0,672746,dan perankingan ke-4 terdapat pada alternatif ke-5 yaitu Kota Jakarta dengan nilai 0,642371, dan perankingan ke-5 terdapat pada alternatif ke-3 yaitu Kota Malang dengan nilai 0,490542.

\section{DAFTAR PUSTAKA}

Buhari. 2016. Penentuan Acara Hafalan Terbaik dalam Kitab Alfiyah Ibnu Malik Menggunakan Metode Weighted Product. Dalam skripsi (hal. 12-14). Pamekasan: Fakultas Mipa Universitas Islam Madura.

Cano, Y. C., Lodwick, W., \& Bede, B. 2014. Single Level Constraint Interval Arithmetic. Jurnal, 32.

Handayani, T., YS, L. W., \& Susyanto, T. 2013. Sistem Pendukung Keputusan Beasiswa Diklat dengan Fuzzy MADM. Ti, 2.

Hartanto, M. B. 2016. Sistem Informasi Pendistribusian Barang pada CV. Jaya Makmur. 4.

Kusumadewi, Hartatik, Harjoko, \& Wardoyo. 2006. Fuzzy Multi Atribut Decision Making (Fuzzy MADM). Yogyakarta: Graha Ilmu.

Nugroho, P. B. 2016. Bilangan Fuzzy. Makalah.

Piegat, A., \& Landowski, M. (2012). Is the Conventional Interval Arithmetic Correct. 1.

Sandiantoro. 2015. Perjalanan dan Perkembangan Industri Batik dan Budaya. Pamekasan: Byzantium Kreative media.

Sastrodiwirjo, K. 2012. Pamekasan Membatik. Pamekasan.

Ula, M. 2014. Implementasi Logika Fuzzy dalam Optimasi Jumlah Pengadaan Barang Menggunakan Metode Tsukamoto. 3-4.

Wibawa, N. C. 2013. Optimalisasi Gula Pasir Menggunakan Metode Linier Programming pada PT. Madubaru PG-PS Madukismo. Dalam Skripsi. Yogyakarta: Universitas Islam Negeri Sunan Kalijaga. 